\title{
The role of mindfulness and perceived social support in promoting students' social entrepreneurial intention
}

\author{
Anh Bui Ngoc Tuan, Minh Pham
}

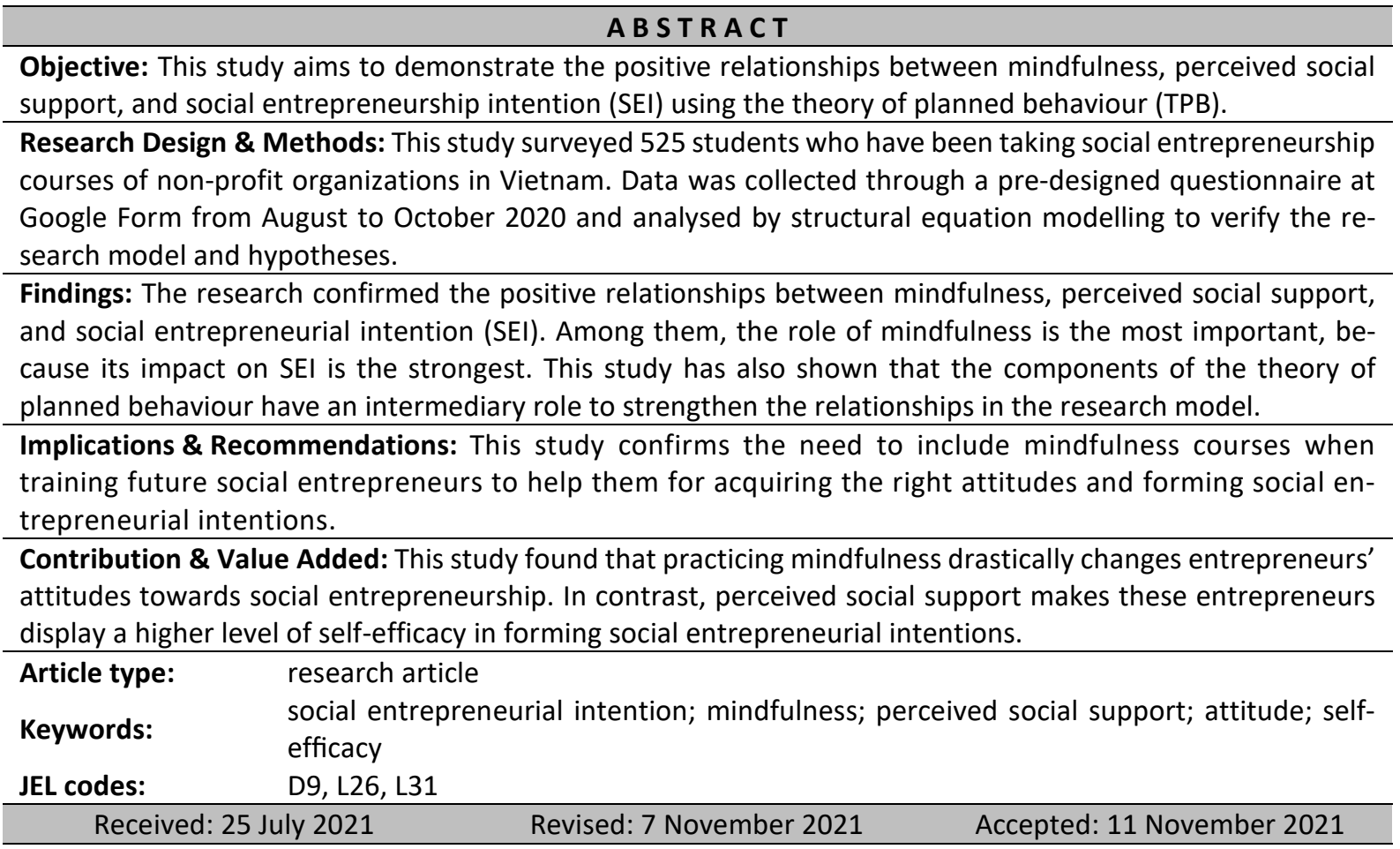

\section{Suggested citation:}

Bui Ngoc Tuan, A., \& Pham, M. (2022). The role of mindfulness and perceived social support in promoting students' social entrepreneurial intention. Entrepreneurial Business and Economics Review, 10(1), 145-160. https://doi.org/10.15678/EBER.2022.100110

\section{INTRODUCTION}

The rapid economic growth and globalization make the process of urbanization, as well as income differentiation, quicker and have left gaps in society (Bourguignon, 2018; Tchamyou, 2020). In addition, non-traditional security factors, natural disasters, epidemics, and climate change with unpredictable happenings have had heavy impact on the production and life of many classes of the population, especially among vulnerable ones (Durante et al., 2017; Guzman \& Oviedo, 2018; Musterd et al., 2017). Hence, social enterprises have emerged as a fill-in gap that governments and commercial enterprises could fill (Hamby et al., 2017; Kickul \& Lyons, 2020). Social enterprises, established to provide economic services and social assistance, as well as to promote social change, have existed in various forms throughout history (Morales et al., 2021). However, governments and scientists have paid little attention to it, especially in transitioning markets.

Social entrepreneurs, founders of social enterprises, pursue social missions (Muñoz \& Kimmitt, 2019) and try to solve social problems through innovative solutions (Ip et al., 2018; Tiwari et al., 2017a; 
Zaremohzzabieh et al., 2019). Social entrepreneurs have provided creative business models that positively handle society's problems and fill gaps in national social welfare programs (Nicholls, 2010). Therefore, many countries have been supporting the development of generations of social entrepreneurs. Academically, understanding how an individual forms of social entrepreneurial intention (SEI) has become an important research goal (Kruse, 2020).

According to Dees (1998), the essence of social entrepreneurship is pursuing a dual mission: creating social and economic value and being an agent of change. This mission makes social entrepreneurship more challenging than ordinary ones (Austin et al., 2006). Therefore, social enterpreneurs need distinct personality traits that motivate them for pursuing this difficult choice (Hsu \& Wang, 2019; Nga \& Shamuganathan, 2010; Smith \& Woodworth, 2012; Stephan \& Drencheva, 2017). However, to be a social entrepreneur, individuals need more than possessing a social personality because they still have to secure the business finances (Berbegal-Mirabent et al., 2021; Mair \& Noboa, 2006).

According to Plaskoff (2012), mindfulness may be a solution to this problem. Besides, in addition to increasing awareness of business opportunities, practicing mindfulness increases compassion, which turns into taking more ethical decisions regarding others (Kelly \& Dorian, 2017). Thus, mindfulness is a precondition for creating motivation for a person to become a social entrepreneur. Wach and Głodowska (2021) argue that research on entrepreneurial traits is still in the developing stage. The addition of mindfulness in the SEI model offers the novelty of exploration for the personal trait of social entrepreneurs. This brings an innovative aspect to the research of the characteristics of social entrepreneurs, which is focused on the Big five model (Bernardino et al., 2018; Tran \& Von Korflesch, 2016). On the other hand, Ip et al. (2018) stated that perceived social support is the antecedent for SEI. Recent empirical studies on SEI show that perceived social support is a factor that receives much attention (Hockerts, 2017; Lacap et al., 2018; Politis et al., 2016). Luc et al. (2019) confirms that perceived social support is one of the factors that are often added to research models on SEI. Bacq and Janssen (2011) argue that understanding local social influence is very important in the research of social entrepreneurship. However, a comparison between mindfulness and perceived social support about SEI has not been done before.

In social psychology research, the models of behavioural intention have been successfully used to predict future behaviour for both managers and policymakers (Wach \& Wojciechowski, 2016), in which the theory of planned behaviour (TPB) is often used for studying on SEI (Luc et al., 2019). The objective of this study is to explore the impacts of mindfulness and perceived social support on SEI by applying the TPB model. From this result, we propose ideas for universities to help them come up with appropriate policies for the development of new generations of social entrepreneurs. On the other hand, this study was also conducted to supplement prior research on the attributes of social entrepreneurs. The objective was achieved via an exploratory study that focused on identifying the essential factors that explain the process of forming SEI.

The structure of the article includes five sections. The first section is the introduction to the research problem. In the second section, the literature review is presented. The third section discusses the design of the research and the methodology. In the fourth section, we present and discuss the results. The last section of the article draws conclusions about the contributions of this study to theory and practice.

\section{LITERATURE REVIEW}

\section{Social entrepreneurial intention}

Shaw and Carter (2007) argue that social entrepreneurship brings value to a community by using resources creatively. Bosch-Badia et al. (2015) agree that social entrepreneurship involves entrepreneurship with the determination to achieve positive social transformation social entrepreneurship takes many different forms, including starting, or transforming existing business, or collaborating with others (Short et al., 2009). So, the definitions clearly state that social entrepreneurship is a process of creating social value based on business principles. Driven by self-motivators, social enterprises look for opportunities that can make social value by doing social changes or responding to social needs. (Zahra et al., 2009). 
As the role of social entrepreneurs becomes more important in socio-economics, academic interest in their SEI has also increased (Krueger et al., 2000). Behavioural intention theories are used to explain why entrepreneurs plan to establish a business or organization before they look for opportunities (Wang et al., 2016). According to Bosma et al. (2016), SEl relates to any type of activity, planning, or idea with specific social, environmental, or community goals. These activities may include providing services or training to people with disabilities, activities for decreasing pollution or waste, organizing community groups (Bosma et al., 2016).

Thus, an individual's SEl is a fine indicator for the start-up of social businesses and also an emerging field of interest for scientists. Researchers have suggested different factors influence SEI such as big five traits (Aure, 2018; Hsu \& Wang, 2019; Ip et al., 2018; Nga \& Shamuganathan, 2010), entrepreneurial personalities (Liu et al., 2020; Politis et al., 2016), social personalities (Bacq \& Alt, 2018; McMullen \& Bergman, 2017; Miller et al., 2012), cognitive factors (Kedmenec et al., 2015; Tiwari et al., 2017a), work requirements and education (Shumate et al., 2014). Researchers emphasize that these factors indirectly affect the intentions of individuals by influencing their attitudes (Krueger \& Kickul, 2006). Therefore, social entrepreneurship is a multi-step process, in which intention has been seen as the first step and should be considered cautiously (Bacq et al., 2016; Dacin et al., 2010; Hockerts, 2017).

However, Ziegler (2011) finds that the prerequisites for motivating individuals to become social entrepreneurs have not been fully explored. Especially in a country with an emerging economy like Vietnam, where many problems need to be solved to both develop the economy and make life and society better. Hence, the research in this field will help solve these problems that arise in society.

\section{Theory of planned behaviour (TPB)}

Ajzen (1991) presents TPB as an improvement to the theory of reasoned action (Ajzen \& Fishbein, 1980). The TPB theory has been used in various research to assess human behaviours in different relationships. For TPB, behavioural intention is the key predictor that makes it easier to measure and evaluate behaviour. In TPB, factors that can influence planned behaviour are the subjective norm, perceived behavioural control, and attitude towards behaviour. The TPB has demonstrated its ability to anticipate and interpret human behaviour in specific situations based on the assumption that human intention is the subject of a motivational state that encourages behaviour (Fayolle \& Liñán, 2014; Sharahiley, 2020; Tiwari et al., 2017a). Researchers often apply the adjusted TPB model with the substitution or addition of appropriate variables according to each research context for helping to better explain behaviours (Alzubaidi et al., 2021; Munir et al., 2019; Shneor \& Munim, 2019). However, the relationship between subjective norm and SEl has not been confirmed in many studies (Kruse et al., 2019; Luc, 2018; Politis et al., 2016). Therefore, this factor is not studied in this article.

Attitude towards behaviour (ATB) is the degree to which the individual likes or dislikes the outcomes that the behaviour produces (Ajzen, 1991). In the context of social entrepreneurship, Kruse et al. (2021) argue that attitude is an assessment of the action. As such, a negative or positive evaluation of the activity reduces or enhances the likelihood of it being executed. Based on the student perspective, ATB is the degree to which students desire or do not desire to make social entrepreneurship behaviours (Lukman et al., 2021). Many researchers have found a positive link between individuals who aspire to be a social entrepreneur and SEI (Ernst, 2011; Luc, 2018; Politis et al., 2016). Hence, our first hypothesis is:

H1: Attitude towards behaviour (ATB) has a positive effect on social entrepreneurial intention (SEI).

Perceived behaviour control refers to an individual's perception of the ability to perform a particular behaviour (Ajzen, 1991). A high level of perceived behavioural control increases endeavour, determination, and intention to commit to the behaviour (Ajzen, 2002). However, perceived behaviour control can be replaced by self-efficacy (SEF) when explaining behavioural intentions (Armitage \& Conner, 2001). Wach and Bilan (2021) argue that these two concepts are equivalent and interchangeable. SEF is considered as a set of competencies of beliefs as seen from the social cognitive perspective (Bandura, 1993). In the context of social entrepreneurship, SEF is defined as an individual's perception of their ability for contributing to social change in finding solutions for social problems (Hockerts, 2017). When people have 
strong SEF in SEI, they are ready to face external obstacles. Since social issues are often quite complex, they pose psychological barriers for potential social entrepreneurs. As a result, SEF can help reduce these barriers to SEI (Hockerts, 2017). The above arguments lead to the following two hypotheses:

H2: Self-efficacy (SEF) has a positive impact on social entrepreneurial intention (SEI).

H3: Self-efficacy (SEF) has a positive impact on attitude towards behaviour (ATB).

\section{Perceived social support}

Perceived social support (PSS) is defined as interactions or relationships of society that make real support or set individuals up in a system that is supposed to provide care or to create a feeling of belonging to a valued community group (Hobfoll, 1988). Social support theory explains that the support received from interpersonal relationships has a positive influence on how an individual responds to stress or life changes. According to Hockerts (2015), in the context of social entrepreneurship, perceived social support is how individuals perceive the degree to which they will be supported by those in their network. Individuals will be impacted by the extent to which they will receive support and assistance in their efforts from people in their networks. Perceived social support also reflects the extent to which individuals believe access to investments is possible when they establish a social enterprise (Nga \& Shamuganathan, 2010).

The support of the close environment (relative, trustworthy and influential person) makes people believe that they are more likely to be suitable and viable for a business career (Liñán \& Chen, 2009). Nowiński et al. (2020) have demonstrated that there is a positive relationship between PSS and entrepreneurial intention mediated by TPB components such as ATB and SEF. The above arguments suggest PSS's role is related to the concepts of social entrepreneurship in limited resource environments, as often happens in developing countries (Desa \& Basu, 2013). Therefore, t he next research hypotheses are:

H4: Perceived social support (PSS) has a positive effect on social entrepreneurial intention (SEI).

H5: Perceived social support (PSS) has a positive effect on attitude towards behaviour (ATB).

H6: Perceived social support (PSS) has a positive effect on self-efficacy (SEF).

\section{Mindfulness}

Mindfulness (MFN) has been studied by researchers in a variety of circumstances, such as psychology, health, business, education, meditation, and social sciences (Brown \& Ryan, 2003; Chatzisarantis \& Hagger, 2007; Dimidjian \& Segal, 2015; Langer \& Moldoveanu, 2000; Ngo et al., 2016; Rahl et al., 2017). Across fields of research, MFN is often described as the focus on or attention on the present moment, and following the feeling of curiosity, openness, and acceptance (Brown \& Ryan, 2003; Langer, 1989; Sternberg, 2000). In these studies, there are important implications that we may improve our MFN level through exercise (Baer, 2003); and that it may enhance work efficiency in volatile decision-making environments (Dane, 2011).

Mindfulness disposition is a characteristic that indicates the degree to which a person pays attention to or is aware of what is happening in the present moment (Brown \& Ryan, 2003). While research shows that dispositional or trait mindfulness can be magnified through repeated practice or reverting to the state of mindfulness (Kiken et al., 2015), this article focuses on MFN as an orientation, regardless of mindfulness practice or not. In entrepreneurship, MFN can help explain how entrepreneurs anticipate and take advantage of opportunities that others may not (Capel, 2014; Rerup, 2005). High levels of MFN can promote entrepreneurial behaviour through increased flexibility in awareness of situations (Gelderen et al., 2019). These are the important prerequisites for an individual to increase SEI. In traditional business, previous studies have demonstrated a link between MFN and start-up intention (Caliendo et al., 2014; Frese \& Gielnik, 2014; Gelderen et al., 2019; Rerup, 2005). Although, Gelderen et al. (2019) declare that individuals with lower levels of mindfulness were more likely to take entrepreneurial action than higher mindful ones, but they also found that individuals with a high level of mindfulness when they have decided to start a business will take more action, even more drastic, if they have business experience. This also makes sense when explaining SEI as entrepreneurs must have consideration and understanding before deciding to enter this field. Therefore, MFN is expected to play an important role in SEI. 
Individuals with high dispositional mindfulness have a deeper awareness and attention to everyday happenings (Dane \& Brummel, 2014). Awareness and clarity of mind also increase people's ability to think more positively (Kabat-Zinn, 1990). Mindfulness creates increased awareness by taking a multidimensional approach and allowing the entrepreneur to see things from the other person's point of view, which makes more empathy and leads to more compassionate and ethical decisions. This is the premise for pursuing the mission of creating and maintaining social value. Miller et al. (2012) demonstrated a link between compassion and social entrepreneurship outcomes, and increased mindfulness has been shown to raise levels of it (McCollum \& Gehart, 2010). In addition, if individuals are characterized by a high MFN level, then they also have more compassion than those who display a low MFN level (Hunter \& McCormick, 2008). It exhibits a strong orientation towards taking care of others (Good et al., 2016). According to Good et al. (2016), MFN increases prosocial behaviours, so it also helps potential entrepreneurs increase attitudes towards SEI.

Moreover, $s$ cientists report that person with a high rank of MFN tends to be more willing to face challenges (Feldman et al., 2007), which has a positive influence on SEF, while it reduces the propensity to procrastinate (Howell \& Buro, 2011). MFN has been shown to promote more adaptation to situations (Vago \& David, 2012). In addition, Keye and Pidgeon (2013) provide recent empirical evidence supporting a positive relationship between MFN and SEF. Following the above arguments, we formulated the last hypotheses:

H7: Mindfulness (MFN) has a positive impact on Social entrepreneurial intention (SEI).

H8: Mindfulness (MFN) has a positive impact on Attitude towards behaviour (ATB).

H9: Mindfulness (MFN) has a positive impact on Self-efficacy (SEF).

From the above research hypotheses, we propose the following research model (Figure 1).

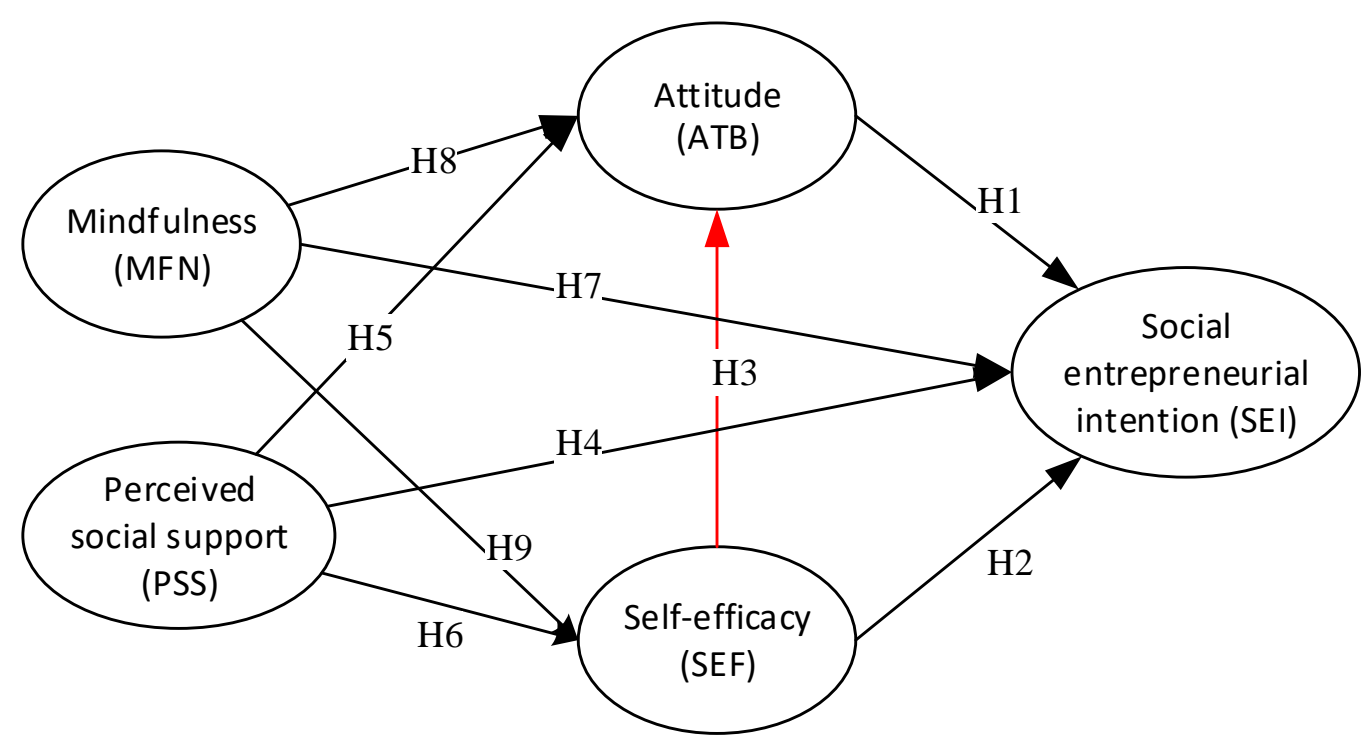

Figure 1. Conceptual framework

Source: own elaboration.

\section{RESEARCH METHODOLOGY}

\section{Sampling method and data collection}

The survey subjects in this article are students who had attended various programs organized by the Supporting Social Enterprise Community (SSEC) and the Centre for Social Initiatives Promotion (CSIP). Both CSIP and SSEC are prominent non-profit organizations in promoting social entrepreneurship in Vietnam. The researchers recommend targeting young people because they are more conscious of their careers and because of the perception that social entrepreneurship is linked with youth (Bosma 
et al., 2016; Hockerts, 2017; Nga \& Shamuganathan, 2010; Tiwari et al., 2017a). The survey participants were students selected by the convenience sampling method.

We collected data using an electronic survey method delivered through Google Forms. The survey was conducted between August 2020 and November 2020. There were 525 valid questionnaires (no missing value) for analysis. In which, the number of male students participating in the survey is 250 (accounting for $47.6 \%$ ). In Table 1., the vast majority of them are students majoring in Economics (accounting for $67.8 \%$ ) and in their first year (accounting for $42.1 \%$ ).

Table 1. Demographic statistics

\begin{tabular}{|l|l|l|l|}
\hline \multicolumn{1}{|c|}{ Variables } & \multicolumn{1}{c|}{ Values } & \multicolumn{1}{c|}{ Prequency } & \multicolumn{1}{|c|}{ Percent (\%) } \\
\hline \multirow{3}{*}{ Gender } & Male & 250 & 47.6 \\
\cline { 2 - 4 } & Female & 275 & 52.4 \\
\hline Academic year & Year 1 & 221 & 42.1 \\
\cline { 2 - 4 } & Year 2 & 121 & 23.0 \\
\cline { 2 - 4 } & Year 3 & 115 & 21.9 \\
\cline { 2 - 4 } & Year 4 and more & 68 & 13.0 \\
\hline \multirow{5}{*}{ Training sector } & Engineering sector & 110 & 21.0 \\
\cline { 2 - 4 } & Economic sector & 356 & 67.8 \\
\cline { 2 - 4 } & Sociological sector & 59 & 11.2 \\
\hline
\end{tabular}

Source: own study.

\section{Measurement}

The questionnaire is commonly used to collect data in advanced scientific studies. This article uses seven -point Likert scales, where one means "strongly disagree" and seven "strongly agree." The scales of research concepts are inherited from previous studies. Specifically, the scales of SEF and PSS are inherited from Hockerts (2017) with three items for each scale. The scales of ATB (five items) and SEI (six items) were designed from the study of Liñán and Chen (2009), while the MFN scale was borrowed from the study of Brown and Ryan (2003) with 15 items. To ensure that the respondents have a correct understanding of social entrepreneurship, the explanation of the definition of social entrepreneurship is provided in the introduction of the questionnaire.

We applied SPSS and AMOS 24 software to analyze the collected data. The research hypotheses were verified by structural equation modelling (SEM) according to Anderson and Gerbing's (1988) process. In the first step, confirmatory factor analysis (CFA) was applied to evaluate construct validity and goodness-of-fit. Hair et al. (2010) said that the construct validity is assessed by the following criteria:

- Standardized regression weight (Factor loading) must not be less than 0.7.

- Average variance extracted (AVE) should be 0.5 or greater to achieve convergence.

- The square root of the AVE should not be less than the inter-correlation between two concepts to provide the discriminant validity.

- The reliability indices such as Cronbach's $\alpha$ (CA) or composite reliability (CR) should not be less than 0.7 to demonstrate the internal consistency of the scales.

Then, we assessed the goodness-of-fit to compare the similarity between the observed and estimated covariance matrices (Hair et al., 2010). The model fit is tested through criteria such as Chi-square/degree of freedom ( $\chi 2 / \mathrm{df}$ ), GFI, TLI, CFI, NFI, RMR, and RMSEA. In the second step, we applied the SEM technique. Then, we tested the hypotheses through the evaluation of the path coefficients (beta). Moreover, the impact intensity of the relationships between the research concepts is also checked in this step. 


\section{RESULTS AND DISCUSSION}

\section{Confirmatory factor analysis}

Construct validity is performed to assess whether a construct's scale adequately measures the intended concept (O'Leary-Kelly \& Vokurka, 1998). The results of Table 2 show that the internal consistency of the scales is guaranteed when the CA and CR values do not fall below the "cut-off" value of 0.7 (the minimum value of both CR and CA is 0.841 on the scale of PSS). The AVEs are also satisfactory when the lowest value is 0.540 (of the MFN scale). At the same time, the factor loadings are also between 0.702 and 0.846 . Thus, the scales in this study have got convergent validity.

Table 2. Construct validity

\begin{tabular}{|l|c|c|c|l|l|l|l|l|l|}
\hline Variables & CR & CA & AVE & Factor Loading & \multicolumn{1}{|c|}{ MFN } & SEI & ATB & PSS & SEF \\
\hline MFN & 0.946 & 0.946 & 0.540 & $0.707-0.800$ & $\mathbf{0 . 7 3 5}$ & & & & \\
\hline SEI & 0.922 & 0.922 & 0.663 & $0.778-0.846$ & $0.593^{* * *}$ & $\mathbf{0 . 8 1 5}$ & & & \\
\hline ATB & 0.862 & 0.863 & 0.557 & $0.702-0.826$ & $0.558^{* * *}$ & $0.727^{* * *}$ & $\mathbf{0 . 7 4 6}$ & & \\
\hline PSS & 0.841 & 0.841 & 0.638 & $0.783-0.820$ & $0.607^{* * *}$ & $0.589^{* * *}$ & $0.525^{* * *}$ & $\mathbf{0 . 7 9 9}$ & \\
\hline SEF & 0.842 & 0.841 & 0.640 & $0.774-0.836$ & $0.530^{* * *}$ & $0.595^{* * *}$ & $0.483^{* * *}$ & $0.577^{* * *}$ & $\mathbf{0 . 8 0 0}$ \\
\hline
\end{tabular}

Significant codes: $* * * \mathrm{p}<0.001$.

Source: own study.

On the other hand, the discriminant validity also should be satisfied. As discussed in the previous section, the square root of the AVE of a concept must not be lower than the correlations of that concept with others in the model. Those square root values (in bold) are all greater than their intercorrelations (in italics), which means that the scales achieve discriminant validity. So, the construct validity has been verified (See Table 2).

Hair et al. (2010) stated that the goodness-of-fit evaluates the difference between the estimated model and the actual values. The goodness-of-fit measures calculated through AMOS 24 software show that they met the requirements (s ee Table 3). This means that the collected data is fitted with the predictions of the estimated model. Thus, after evaluating the CFA, the data are suitable for SEM analysis.

Table 3. Goodness-of-fit

\begin{tabular}{|c|c|c|c|}
\hline Criteria & Values & Cut-off & Sources \\
\hline$\chi^{2} / d f$ & 1.785 & $<3$ & \multirow[t]{5}{*}{$\mathrm{Hu}$ and Bentler (1999) } \\
\hline GFI & 0.909 & $>0.9$ & \\
\hline TLI & 0.962 & $>0.9$ & \\
\hline $\mathrm{CFI}$ & 0.966 & $>0.95$ & \\
\hline $\mathrm{NFI}$ & 0.925 & $>0.9$ & \\
\hline RMR & 0.054 & $<0.08$ & \multirow[t]{2}{*}{ Taylor et al. (1993) } \\
\hline RMSEA & 0.039 & $<0.08$ & \\
\hline
\end{tabular}

Source: own study.

\section{Structural model assessment and discussions}

According to Figure 2 and Table 4, the path coefficients are all positive. This means that the above research hypotheses are all accepted. Specifically, ATB had the strongest effect on SEI ( $\beta=0.487)$, while SEF had a weaker effect $(\beta=0.221)$. This is surprising as it contrasts with the results of Tiwari et al. (2017b). It can be explained by the fact that SEl is a new concept in Vietnam. Vietnam is a Southeast Asian country, with a culture that pursues stability. According to Hofstede (1993), people of this culture often tend to resist unknown situations. Therefore, Vietnamese students are not confident about becoming social entrepreneurs.

The results also show that the standardized direct effects of MFN and PSS on SEI are quite small with $\beta$ coefficients of 0.154 and 0.139 , respectively (See Table 4). However, in Table 5 , the results have demonstrated the intermediate effects of TPB components. Specifically, through ATB and SEF, the in- 
direct effects of MFN and PSS on SEI have $\beta$ of 0.292 and 0.241 . That is why the total effects of MFN and PSS on SEI are stronger than the direct effect of SEF on SEI (with $\beta$ of 0.446 and 0.380 , respectively).

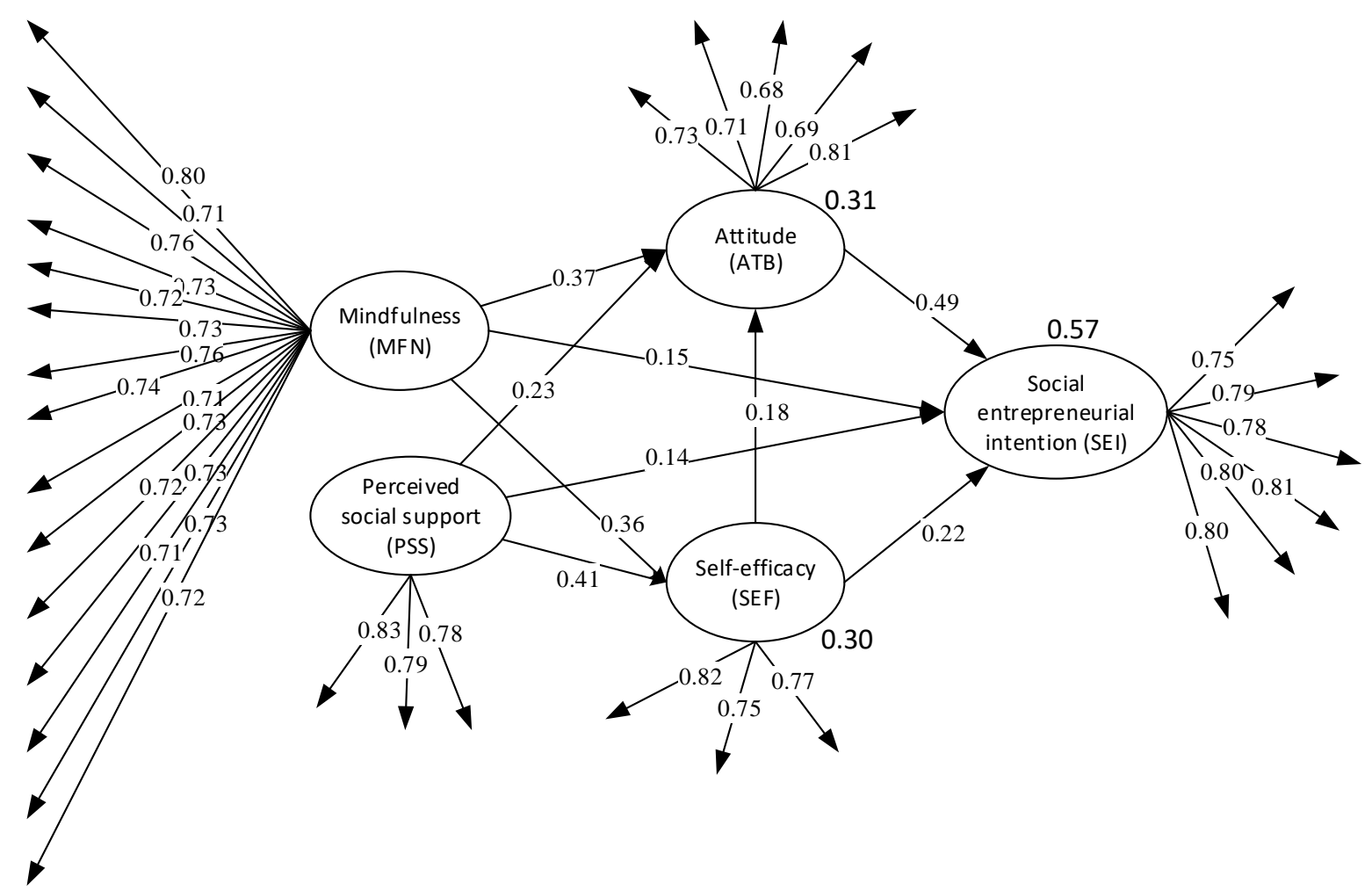

Figure 2. Structural model

Source: own elaboration.

Table 4. Hypothesis testing

\begin{tabular}{|r|c|l|r|r|r|r|c|}
\hline \multicolumn{2}{|c|}{ Hypothesis } & Path coefficients & S.E. & C.R. & p-value & Results \\
\hline SEF & $<---$ & MFN & 0.356 & 0.045 & 7.670 & $* * *$ & Accepted \\
\hline SEF & $<---$ & PSS & 0.413 & 0.048 & 8.289 & $* * *$ & Accepted \\
\hline ATB & $<---$ & MFN & 0.373 & 0.049 & 7.459 & $* * *$ & Accepted \\
\hline ATB & $<---$ & PSS & 0.232 & 0.051 & 4.374 & $* * *$ & Accepted \\
\hline ATB & $<---$ & SEF & 0.180 & 0.058 & 3.122 & 0.002 & Accepted \\
\hline SEI & $<---$ & MFN & 0.154 & 0.042 & 3.621 & $* * *$ & Accepted \\
\hline SEI & $<---$ & PSS & 0.139 & 0.044 & 3.146 & 0.002 & Accepted \\
\hline SEI & $<---$ & ATB & 0.487 & 0.052 & 9.674 & $* * *$ & Accepted \\
\hline SEI & $<---$ & SEF & 0.221 & 0.049 & 4.596 & $* * *$ & Accepted \\
\hline
\end{tabular}

Significant codes: ${ }^{* * *} \mathrm{p}<0.001$.

Source: own study.

Another finding of this study was the effects of MFN and PSS on components of TPB. The MFN is found to have a stronger impact on respondents' attitudes towards social enterprises $(\beta=0.437)$ than their SEF $(\beta=0.307)$. This shows that practicing mindfulness will help people have a more positive attitude towards the community (Kelly \& Dorian, 2017). In contrast, PSS helps people increase their confidence when deciding to become social entrepreneurs. Indeed, Liñán and Chen (2009) suggest that people are more confident in their behaviour when they are supported by the external environment. Therefore, PSS has a more important role than MFN in enhancing the SEF of potential social entrepreneurs $(\beta=0.413>0.356)$. 
Thus, the research results confirm the role of MFN and PSS in SEI formation, in which MFN has the greatest impact (See Table 5). This result confirms Plaskoff's (2012) statement about using mindfulness to explain social entrepreneurship as a way of integrating heart and mind; as well as affirming mindfulness as an important personality trait of SEI (Chinchilla \& Garcia, 2017). This is one of the first empirical studies on the relationship between MFN and SEI. It is a necessary complement to studies on the characteristics of social entrepreneurs, which have been centred around the Big five model (Bernardino et al., 2018; Tran \& Von Korflesch, 2016).

Table 5. Standardized indirect and total effects

\begin{tabular}{|l|c|c|c|c|}
\hline \multicolumn{1}{|c|}{ Variables } & PSS & MFN & SEF & ATB \\
\hline SEF & $0.413^{* * *}$ & $0.356^{* * *}$ & & \\
& 0 & 0 & $0.180^{*}$ & \\
\hline ATB & $0.307^{* * *}$ & $0.437^{* * *}$ & 0 & $0.487^{* * *}$ \\
& 0.074 & 0.064 & $0.309 * * *$ & 0 \\
\hline SEI & $0.380^{*}$ & $0.446^{* * *}$ & 0.088 & 0.292 \\
\end{tabular}

Significant codes: 0 '***' $0.001^{\prime * * \prime} 0.01^{\prime * \prime} 0.05^{\prime \prime} 0.1^{\prime \prime} 1$

Italics number: Indirect effect

Normal number: Total effect

Source: own study.

Thus, the research results confirm the role of MFN and PSS in SEI formation, in which MFN has the greatest impact (See Table 5). This result confirms Plaskoff's (2012) statement about using mindfulness to explain social entrepreneurship as a way of integrating heart and mind; as well as affirming mindfulness as an important personality trait of SEI (Chinchilla \& Garcia, 2017). This is one of the first empirical studies on the relationship between MFN and SEI. It is a necessary complement to studies on the characteristics of social entrepreneurs, which have been centred around the Big five model (Bernardino et al., 2018; Tran \& Von Korflesch, 2016).

\section{CONCLUSIONS}

This article has completed the research objective of finding out the positive relationship of MFN, PSS with SEI of students in Vietnam. On the other hand, this research also demonstrated a significant mediating effect of TPB model components in the above relationships.

From the research results, we suggest the following for university leaders and policymakers. Firstly, mindfulness plays an important role in shaping the SEI of potential entrepreneurs. The practice of mindfulness should receive more attention from policymakers and training institutions to help individuals gain a more favourable view of social enterprises. Baer (2003) suggests that mindfulness can be enhanced through practice. Therefore, this training helps students improve their attitudes towards social problems and thereby enhance their SEI.

Secondly, the relationship between PSS and SEI has the weakest correlation, but social support plays an important role in students' self-efficacy (See table 5 ). Therefore, having policies to support students will help them gain more confidence in their intention to become an entrepreneur (Nowiński et al., 2020). According to Desa and Basu (2013), in areas where other support resources are lacking, such as in Vietnam, receiving support from both the university and the government increases student's motivation in terms of their chosen social careers.

Due to the selection of survey subjects and due to financial constraints, this study has some limitations. Firstly, this research studied SEI from the students' perspectives. Although young people are fit for research on social entrepreneurship (Bosma et al., 2016), next studies should extend the research model testing to other survey subjects. This helps prove the research model is suitable for different subjects. Secondly, the data collection was conducted in only one country, making the results of the study not general. The expansion of model testing in other countries deserves the attention of 
further studies. On the other hand, the convenience sampling method has low reliability. Further studies should use probabilistic sampling methods to obtain more representative survey samples. Finally, scientists should evaluate the mediation of demographic factors in the model's relationships such as comparisons between students of different disciplines, or between students who have attended mindfulness courses with people who have not, and so on.

\section{REFERENCES}

Ajzen, I. (1991). The theory of planned behavior. Organizational Behavior and Human Decision Processes, 50(2), 179-211. https://doi.org/10.1016/0749-5978(91)90020-T

Ajzen, I. (2002). Perceived behavioral control, self-efficacy, locus of control, and the theory of planned behavior. Journal of Applied Social Psychology, 32(4), 665-683. https://doi.org/10.1111/j.1559-1816.2002.tb00236.x

Ajzen, I., \& Fishbein, M. (1980). Understanding attitudes and predicting social behavior. Englewood Cliffs, N.J.: Prentice Hall.

Alzubaidi, H., Slade, E. L., \& Dwivedi, Y. K. (2021). Examining antecedents of consumers' pro-environmental behaviours: TPB extended with materialism and innovativeness. Journal of Business Research, 122, 685-699. https://doi.org/10.1016/j.jbusres.2020.01.017

Anderson, J. C., \& Gerbing, D. W. (1988). Structural equation modeling in practice: A review and recommended two-step approach. Psychological Bulletin, 103(3), 411-423. http://dx.doi.org/10.1037/0033-2909.103.3.411

Armitage, C. J., \& Conner, M. (2001). Efficacy of the theory of planned behaviour: A meta-analytic review. British Journal of Social Psychology, 40(4), 471-499. https://doi.org/10.1007/s10551-008-9939-1

Aure, P. A. H. (2018). Exploring the social entrepreneurial intentions of senior high school and college students in a Philippine university: A PLS-SEM approach. Journal of Legal, Ethical and Regulatory Issues, 21(2), 1-11.

Austin, J., Stevenson, H., \& Wei-Skillern, J. (2006). Social and Commercial Entrepreneurship: Same, Different, or Both? Entrepreneurship Theory and Practice, 30(1), 1-22. https://doi.org/10.1111/j.1540-6520.2006.00107.x

Bacq, S., \& Alt, E. (2018). Feeling capable and valued: A prosocial perspective on the link between empathy and social entrepreneurial intentions. Journal of Business Venturing, 33(3), 333-350. https://doi.org/10.1016/j.jbusvent.2018.01.004

Bacq, S., Hartog, C., \& Hoogendoorn, B. (2016). Beyond the Moral Portrayal of Social Entrepreneurs: An Empirical Approach to Who They Are and What Drives Them. Journal of Business Ethics, 133, 703-718. https://doi.org/10.1007/s10551-014-2446-7

Bacq, S., \& Janssen, F. (2011). The multiple faces of social entrepreneurship: A review of definitional issues based on geographical and thematic criteria. Entrepreneurship \& Regional Development, 23(5-6), 373-403. https://doi.org/10.1080/08985626.2011.577242

Baer, R. A. (2003). Mindfulness training as a clinical intervention: A conceptual and empirical review. Clinical psychology: Science and Practice, 10(2), 125-143. https://doi.org/10.1093/clipsy.bpg015

Bandura, A. (1993). Perceived self-efficacy in cognitive development and functioning. Educational Psychologist, 28(2), 117-148. https://doi.org/10.1207/s15326985ep2802_3

Berbegal-Mirabent, J., Mas-Machuca, M., \& Guix, P. (2021). Impact of mission statement components on social enterprises' performance. Review of Managerial Science, 15(3), 705-724. https://doi.org/0.1007/s11846-019-00355-2

Bernardino, S., Santos, J. F., \& Ribeiro, J. C. (2018). Social entrepreneur and gender: what's personality got to do with it? International Journal of Gender and Entrepreneurship, 10(1), 61-82. https://doi.org/10.1108/IJGE-07-2017-0040

Bosch-Badia, M.-T., Montllor-Serrats, J., \& Tarrazon-Rodon, M.-A. (2015). Corporate social responsibility: A real options approach to the challenge of financial sustainability. PloS one, 10(5), e0125972. https://doi.org/10.1371/journal.pone.0125972

Bosma, N., Schøtt, T., Terjesen, S. A., \& Kew, P. (2016). Global entrepreneurship monitor 2015 to 2016: special topic report on social entrepreneurship. Retrievedf form: https://www.american.edu/kogod/research/innovation/upload/gem-2015-report-on-social-entrepreneurship.pdf on July 25, 2021.

Bourguignon, F. (2018). World changes in inequality: An overview of facts, causes, consequences, and policies. CESifo Economic Studies, 64(3), 345-370. https://doi.org/10.1093/cesifo/ifx028 
Brown, K. W., \& Ryan, R. M. (2003). The benefits of being present: mindfulness and its role in psychological wellbeing. Journal of Personality and Social psychology, 84(4), 822. https://doi.org/10.1037/0022-3514.84.4.822

Caliendo, M., Fossen, F., \& Kritikos, A. S. (2014). Personality characteristics and the decisions to become and stay self-employed. Small Business Economics, 42(4), 787-814. https://doi.org/10.1007/s11187-013-9514-8

Capel, C. (2014). Mindfulness, indigenous knowledge, indigenous innovations and entrepreneurship. Journal of Research in Marketing and Entrepreneurship, 16(1), 63-83. https://doi.org/10.1108/JRME-10-2013-0031

Chatzisarantis, N. L., \& Hagger, M. S. (2007). Mindfulness and the intention-behavior relationship within the theory of planned behavior. Personality and Social Psychology Bulletin, 33(5), 663-676. https://doi.org/10.1177/0146167206297401

Chinchilla, A., \& Garcia, M. (2017). Social Entrepreneurship Intention: Mindfulness Towards a Duality of Objectives. Humanistic Management Journal, 1(2), 205-214. https://doi.org/10.1007/s41463-016-0013-3

Dacin, P. A., Dacin, M. T., \& Matear, M. (2010). Social entrepreneurship: Why we don't need a new theory and how we move forward from here. Academy of Management Perspectives, 24(3), 37-57. https://doi.org/10.5465/AMP.2010.52842950

Dane, E. (2011). Paying Attention to Mindfulness and Its Effects on Task Performance in the Workplace. Journal of Management, 37(4), 997-1018. https://doi.org/10.1177/0149206310367948

Dane, E., \& Brummel, B. J. (2014). Examining workplace mindfulness and its relations to job performance and turnover intention. Human Relations, 67, 105-128. https://doi.org/10.1177/0018726713487753

Dees, J.G. (1998). The meaning of "social entrepreneurship". Comments and suggestions contributed from the Social Entrepreneurship Founders Working Group. Durham, NC: Center for the Advancement of Social Entrepreneurship, Fuqua School of Business, Duke University. Retrieved from: http://faculty.fuqua.duke.edu/centers/case/files/dees-SE.pdf on July 25, 2021

Desa, G., \& Basu, S. (2013). Optimization or Bricolage? Overcoming Resource Constraints in Global Social Entrepreneurship. Strategic Entrepreneurship Journal, 7(1), 26-49. https://doi.org/10.1002/sej.1150

Dimidjian, S., \& Segal, Z. V. (2015). Prospects for a clinical science of mindfulness-based intervention. American Psychologist, 70(7), 593-620. https://doi.org/10.1037/a0039589

Durante, F., Tablante, C. B., \& Fiske, S. T. (2017). Poor but warm, rich but cold (and competent): Social classes in the stereotype content model. Journal of Social Issues, 73(1), 138-157. https://doi.org/10.1111/josi.12208

Ernst, K. (2011). Heart over mind-An empirical analysis of social entrepreneurial intention formation on the basis of the theory of planned behaviour (Doctoral dissertation, Universität Wuppertal, Fakultät für Wirtschaftswissenschaft/Schumpeter School of Business and Economics» Dissertationen).

Fayolle, A., \& Liñán, F. (2014). The future of research on entrepreneurial intentions. Journal of Business Research, 67(5), 663-666. https://doi.org/10.1016/j.jbusres.2013.11.024

Feldman, G., Hayes, A., Kumar, S., Greeson, J., \& Laurenceau, J.-P. (2007). Mindfulness and emotion regulation: The development and initial validation of the Cognitive and Affective Mindfulness Scale-Revised (CAMS-R). Journal of Psychopathology and Behavioral Assessment, 29(3), 177-190. https://doi.org/10.1007/s10862-006-9035-8

Frese, M., \& Gielnik, M. M. (2014). The psychology of entrepreneurship. Annu. Rev. Organ. Psychol. Organ. Behav., 1(1), 413-438. https://doi.org/10.1146/annurev-orgpsych-031413-091326

Gelderen, V., M., K., E., K., T., Munoz, P., \& Wincent, J. (2019). Mindfulness and Taking Action to Start a New Business. Journal of Small Business Management, 57(2), 489-506. https://doi.org/10.1111/jsbm.12499

Good, D. J., Lyddy, C. J., Glomb, T. M., Bono, J. E., Brown, K. W., Duffy, M. K., Baer, R. A., Brewer, J. A., \& Lazar, S. W. (2016). Contemplating mindfulness at work: An integrative review. Journal of Management, 42, 114-142. https://doi.org/10.1177/0149206315617003

Guzman, L. A., \& Oviedo, D. (2018). Accessibility, affordability and equity: Assessing 'pro-poor'public transport subsidies in Bogotá. Transport Policy, 68, 37-51. https://doi.org/10.1016/j.tranpol.2018.04.012

Hair, J. F., Black, W. C., Babin, B. J., \& Anderson, R. E. (2010). Multivariate data analysis: International version. Edinburgh Gate, England: Pearson Education.

Hamby, A., Pierce, M., \& Brinberg, D. (2017). Solving complex problems: Enduring solutions through social entrepreneurship, community action, and social marketing. Journal of Macromarketing, 37(4), 369-380. https://doi.org/10.1177/0276146716663797

Hobfoll, S. E. (1988). The ecology of stress. USA: Taylor \& Francis. 
Hockerts, K. (2015). The Social Entrepreneurial Antecedents Scale (SEAS): A Validation Study. Social Enterprise Journal, 11(3), 260-280. https://doi.org/10.1108/SEJ-05-2014-0026

Hockerts, K. (2017). Determinants of social entrepreneurial intentions. Entrepreneurship Theory and Practice, 41(1), 105-130. https://doi.org/10.1111/etap.12171

Hofstede, G. (1993). Cultural constraints in management theories. Academy of Management Perspectives, $7(1)$, 81-94. https://doi.org/10.5465/ame.1993.9409142061

Howell, A. J., \& Buro, K. (2011). Relations among mindfulness, achievement-related self-regulation, and achievement emotions. Journal of Happiness Studies, 12(6), 1007-1022. https://doi.org/10.1007/s10902-010-9241-7

Hsu, C.-Y., \& Wang, S.-M. (2019). Social entrepreneurial intentions and its influential factors: A comparison of students in Taiwan and Hong Kong. Innovations in Education and Teaching International, 56(3), 385-395. https://doi.org/10.1080/14703297.2018.1427611

Hunter, J., \& McCormick, D. W. (2008). Mindfulness in the workplace: An exploratory study. Paper presented at the Academy of Management Annual Meeting, Anaheim, CA. Retrieved from: https://www.researchgate.net/profile/Donald-Mccormick/publication/266371684_Mindfulness_in_the_Workplace_An_Exploratory_Study/links/54ff31b80cf2672e2243d844/Mindfulness-in-the-Workplace-An-Exploratory-Study.pdf on July 25, 2021

Ip, C. Y., Liang, C., Wu, S.-C., Law, K. M. Y., \& Liu, H.-C. (2018). Enhancing social entrepreneurial intentions through entrepreneurial creativity: A comparative study between Taiwan and Hong Kong. Creativity Research Journal, 30(2), 132-142. https://doi.org/10.1080/10400419.2018.1446744

Kabat-Zinn, J. (1990). Full catastrophe living:Using the wisdom of your body and mind to face stress, pain, and illness. New York: Delacorte.

Kedmenec, I., Rebernik, M., \& Perić, J. (2015). The impact of individual characteristics on intentions to pursue social entrepreneurship. Ekonomski Pregled, 66(2), 119-137. https://hrcak.srce.hr/139350

Kelly, L., \& Dorian, M. (2017). Doing well and good: an exploration of the role of mindfulness in the entrepreneurial opportunity recognition and evaluation process. New England Journal of Entrepreneurship, $20(2), 2$. https://doi.org/10.1108/NEJE-20-02-2017-B002

Keye, M. D., \& Pidgeon, A. M. (2013). Investigation of the relationship between resilience, mindfulness, and academic self-efficacy. Open Journal of Social Sciences, 1(6), 1-4. https://doi.org/10.4236/jss.2013.16001

Kickul, J., \& Lyons, T. S. (2020). Understanding social entrepreneurship: The relentless pursuit of mission in an ever changing world. New York, USA: Routledge. https://doi.org/10.4324/9780429270406

Kiken, L. G., Garland, E. L., Bluth, K., Palsson, O. S., \& Gaylord, S. A. (2015). From a state to a trait: Trajectories of state mindfulness in meditation during intervention predict changes in trait mindfulness. Personality and Individual differences, 81, 41-46. https://doi.org/10.1016/j.paid.2014.12.044

Krueger, N. F., \& Kickul, J. (2006). So you thought the intentions model was simple? Proceedings of the 2006 USASBE Conference, Tucson, Az. Retrieved from: https://papers.ssrn.com/sol3/papers.cfm?abstract_id= 1150881 on July 25, 2021

Krueger, N. F., Reilly, M. D., \& Carsrud, A. L. (2000). Competing models of entrepreneurial intentions. Journal of Business Venturing, 15(5-6), 411-432. https://doi.org/10.1016/S0883-9026(98)00033-0

Kruse, P. (2020). Can there only be one?-an empirical comparison of four models on social entrepreneurial intention formation. International Entrepreneurship and Management Journal, 16, 641-665. https://doi.org/10.1007/s11365-019-00608-2

Kruse, P., Wach, D., Costa, S., \& Moriano, J. A. (2019). Values matter, Don't They?-combining theory of planned behavior and personal values as predictors of social entrepreneurial intention. Journal of Social Entrepreneurship, 10(1), 55-83. https://doi.org/10.1080/19420676.2018.1541003

Kruse, P., Wach, D., \& Wegge, J. (2021). What motivates social entrepreneurs? A meta-analysis on predictors of the intention to found a social enterprise. Journal of Small Business Management, 59(3), 477-508. https://doi.org/10.1080/00472778.2020.1844493

Lacap, J. P. G., Mulyaningsih, H. D., \& Ramadani, V. (2018). The mediating effects of social entrepreneurial antecedents on the relationship between prior experience and social entrepreneurial intent: The case of Filipino and Indonesian university students. Journal of Science and Technology Policy Management, 9(3), 329-346. https://doi.org/10.1108/JSTPM-03-2018-0028 
Langer, E. J. (1989). Minding matters: The consequences of mindlessness-mindfulness. Advances in experimental social psychology, 22, 137-173. https://doi.org/10.1016/S0065-2601(08)60307-X

Langer, E. J., \& Moldoveanu, M. (2000). Mindfulness research and the future. Journal of Social Issues, 56(1), 129139. https://doi.org/10.1111/0022-4537.00155

Liñán, F., \& Chen, Y. W. (2009). Development and cross-cultural application of a specific instrument to measure entrepreneurial intentions. Entrepreneurship Theory and Practice, 33(3), 593-617. https://doi.org/10.1111/j.1540-6520.2009.00318.x

Liu, H.-C., Liang, C., Chang, C.-C., Ip, C. Y., \& Liang, C.-T. (2020). Optimizing Personality Traits and Entrepreneurial Creativity to Boost the Precursors of Social Entrepreneurial Intentions: Five Studies in Taiwan. Journal of Social Service Research, 47, 1-23. https://doi.org/10.1080/01488376.2019.1708840

Luc, P. T. (2018). The relationship between perceived access to finance and social entrepreneurship intentions among university students in Vietnam. The Journal of Asian Finance, Economics, and Business, 5(1), 63-72. https://doi.org/10.13106/jafeb.2018.vol5.no1.63

Luc, P. T., Angelina, L. N. H., \& Lan, P. X. (2019). A Systematic Literature Review on Social Entrepreneurial Intention. Journal of Social Entrepreneurship, 11(3), 241-256. https://doi.org/10.1080/19420676.2019.1640770

Lukman, S., Bao, P. X., Kweku-Lugu, B., Arkorful, V. E., Latif, A., Gadabu, A., Charmaine-Kwade, P., Basiru, I., \& Sadiq, M. A. (2021). Diasporan students social entrepreneurship intention: The moderating role of institutional support. Journal of Public Affairs, 21(1), e2108. https://doi.org/10.1002/pa.2108

Mair, J., \& Noboa, E. (2006). Social entrepreneurship: How intentions to create a social venture are formed. Palgrave Macmillan, London. https://doi.org/10.1057/9780230625655_8

McCollum, E. E., \& Gehart, D. R. (2010). Using mindfulness meditation to teach beginning therapists therapeutic presence: A qualitative study. Journal of Marital and Family Therapy, 36(3), 347-360. https://doi.org/10.1111/j.1752-0606.2010.00214.x

McMullen, J. S., \& Bergman, B. J. (2017). Social entrepreneurship and the development paradox of prosocial motivation: A cautionary tale. Strategic Entrepreneurship Journal, 11(3), 243-270. https://doi.org/10.1002/sej.1263

Miller, T. L., Grimes, M. G., McMullen, J. S., \& Vogus, T. J. (2012). Venturing for others with heart and head: How compassion encourages social entrepreneurship. Academy of Management Review, 37(4), 616-640. https://doi.org/10.5465/amr.2010.0456

Morales, A., Calvo, S., Martínez, J. M. G., \& Martín, J. M. M. (2021). Hybrid forms of business: Understanding the development of indigenous social entrepreneurship practices. Journal of Business Research, 124, 212-222. https://doi.org/10.1016/j.jbusres.2020.11.060

Munir, H., Jianfeng, C., \& Ramzan, S. (2019). Personality traits and theory of planned behavior comparison of entrepreneurial intentions between an emerging economy and a developing country. International Journal of Entrepreneurial Behavior \& Research, 25(3), 554-580. https://doi.org/10.1108/IJEBR-05-2018-0336

Muñoz, P., \& Kimmitt, J. (2019). Social mission as competitive advantage: A configurational analysis of the strategic conditions of social entrepreneurship. Journal of Business Research, 101, 854-861. https://doi.org/10.1016/j.jbusres.2018.11.044

Musterd, S., Marcińczak, S., Van Ham, M., \& Tammaru, T. (2017). Socioeconomic segregation in European capital cities. Increasing separation between poor and rich. Urban Geography, 38(7), 1062-1083. https://doi.org/10.1080/02723638.2016.1228371

Nga, J. K. H., \& Shamuganathan, G. (2010). The influence of personality traits and demographic factors on social entrepreneurship start up intentions. Journal of Business Ethics, 95(2), 259-282. https://doi.org/10.1007/s10551-009-0358-8

Ngo, L. V., Northey, G., Duffy, S., Thao, H. T. P., \& Tam, L. T. H. (2016). Perceptions of others, mindfulness, and brand experience in retail service setting. Journal of Retailing and Consumer Services, 33, 43-52. https://doi.org/10.1016/j.jretconser.2016.07.003

Nicholls, A. (2010). The legitimacy of social entrepreneurship: Reflexive isomorphism in a pre-paradigmatic field. Entrepreneurship Theory and Practice, 34(4), 611-633. https://doi.org/10.1111/j.1540-6520.2010.00397.x

Nowiński, W., Haddoud, M. Y., Wach, K., \& Schaefer, R. (2020). Perceived public support and entrepreneurship attitudes: A little reciprocity can go a long way!. Journal of Vocational Behavior, 121, 103474. https://doi.org/10.1016/j.jvb.2020.103474 
O'Leary-Kelly, S. W., \& Vokurka, R. J. (1998). The empirical assessment of construct validity. Journal of Operations Management, 16(4), 387-405. https://doi.org/10.1016/S0272-6963(98)00020-5

Plaskoff, J. (2012). Building the heart and the mind: An interview with leading social entrepreneur Sarah Harris. Academy of Management Learning \& Education, 11(3), 432-441. https://doi.org/10.5465/amle.2011.0010

Politis, K., Ketikidis, P., Diamantidis, A. D., \& Lazuras, L. (2016). An investigation of social entrepreneurial intentions formation among South-East European postgraduate students. Journal of Small Business and Enterprise Development, 23, 1120-1141. https://doi.org/10.1108/JSBED-03-2016-0047

Rahl, H. A., Lindsay, E. K., Pacilio, L. E., Brown, K. W., \& Creswell, J. D. (2017). Brief mindfulness meditation training reduces mind wandering: The critical role of acceptance. Emotion, 17(2), 224-230. https://doi.org/10.1037/emo0000250

Rerup, C. (2005). Learning from past experience: Footnotes on mindfulness and habitual entrepreneurship. Scandinavian Journal of Management, 21(4), 451-472. https://doi.org/10.1016/j.scaman.2005.09.010

Sharahiley, S. M. (2020). Examining entrepreneurial intention of the Saudi Arabia's University students: Analyzing alternative integrated research model of TPB and EEM. Global Journal of Flexible Systems Management, 21(1), 67-84. https://doi.org/10.1007/s40171-019-00231-8

Shaw, E., \& Carter, S. (2007). Social entrepreneurship: Theoretical antecedents and empirical analysis of entrepreneurial processes and outcomes. Journal of Small Business and Enterprise Development, 14(3), 418-434. https://doi.org/10.1108/14626000710773529

Shneor, R., \& Munim, Z. H. (2019). Reward crowdfunding contribution as planned behaviour: An extended framework. Journal of Business Research, 103, 56-70. https://doi.org/10.1016/j.jbusres.2019.06.013

Short, J. C., Moss, T. W., \& Lumpkin, G. T. (2009). Research in social entrepreneurship: Past contributions and future opportunities. Strategic Entrepreneurship Journal, 3(2), 161-194. https://doi.org/10.1002/sej.69

Shumate, M., Atouba, Y., Cooper, K. R., \& Pilny, A. (2014). Two paths diverged: Examining the antecedents to social entrepreneurship. Management Communication Quarterly, 28(3), 404-421. https://doi.org/10.1177/0893318914538561

Smith, I. H., \& Woodworth, W. P. (2012). Developing social entrepreneurs and social innovators: A social identity and self-efficacy approach. Academy of Management Learning \& Education, 11(3), 390-407. https://doi.org/10.5465/amle.2011.0016

Stephan, U. \& Drencheva, A. (2017). The person in social entrepreneurship: A systematic review of research on the social entrepreneurial personality (pp. 205-230). In G. Ahmetoglu, T. Chamorro-Premuzic, B. Klinger, \& T. Karcisky (Eds.), The Wiley Handbook of Entrepreneurship. Chichester, UK: John Wiley \& Sons Ltd. https://doi.org/10.1002/9781118970812

Sternberg, R. J. (2000). Images of mindfulness. Journal of Social Issues, 56(1), 11-26. https://doi.org/10.1111/0022-4537.00149

Tchamyou, V. S. (2020). Education, lifelong learning, inequality and financial access: Evidence from African countries. Contemporary Social Science, 15(1), 7-25. https://doi.org/10.1080/21582041.2018.1433314

Tiwari, P., Bhat, A. K., \& Tikoria, J. (2017a). Predictors of social entrepreneurial intention: an empirical study. South Asian Journal of Business Studies, 6(1), 53-79. https://doi.org/10.1108/SAJBS-04-2016-0032

Tiwari, P., Bhat, A. K., \& Tikoria, J. (2017b). The role of emotional intelligence and self-efficacy on social entrepreneurial attitudes and social entrepreneurial intentions. Journal of Social Entrepreneurship, 8(2), 165-185. https://doi.org/10.1080/19420676.2017.1371628

Tran, A. T. P., \& Von Korflesch, H. (2016). A conceptual model of social entrepreneurial intention based on the social cognitive career theory. Asia Pacific Journal of Innovation and Entrepreneurship, 10(1), 17-38. https://doi.org/10.1108/APJIE-12-2016-007

Vago, D. R., \& David, S. A. (2012). Self-awareness, self-regulation, and self-transcendence (S-ART): a framework for understanding the neurobiological mechanisms of mindfulness. Frontiers in Human Neuroscience, 6, 296. https://doi.org/10.3389/fnhum.2012.00296

Wach, K., \& Bilan, S. (2021). Public support and administration barriers towards entrepreneurial intentions of students in Poland. Administratie si Management Public, 36(1), 67-80. https://doi.org/10.24818/amp/2021.36-04

Wach, K., \& Głodowska, A. (2021). How do demographics and basic traits of an entrepreneur impact the internationalization of firms?. Oeconomia Copernicana, 12(2), 399-424. https://doi.org/10.24136/oc.2021.014 
Wach, K., \& Wojciechowski, L. (2016). Entrepreneurial intentions of students in Poland in the view of Ajzen's theory of planned behaviour. Entrepreneurial Business and Economics Review, 4(1), 83-94. https://doi.org/10.15678/eber.2016.040106

Wang, J.-H., Chang, C.-C., Yao, S.-N., \& Liang, C. (2016). The contribution of self-efficacy to the relationship between personality traits and entrepreneurial intention. Higher Education, 72(2), 209-224. https://doi.org/10.1007/s10734-015-9946-y

Zahra, S. A., Gedajlovic, E., Neubaum, D. O., \& Shulman, J. M. (2009). A typology of social entrepreneurs: Motives, search processes and ethical challenges. Journal of Business Venturing, 24(5), 519-532. https://doi.org/10.1016/j.jbusvent.2008.04.007

Zaremohzzabieh, Z., Ahrari, S., Krauss, S. E., Abu Samah, A., Meng, L. K., \& Ariffin, Z. (2019). Predicting social entrepreneurial intention: A meta-analytic path based on the theory of planned behavior. Journal of Business Research, 96, 264-276. https://doi.org/10.1016/j.jbusres.2018.11.030

Ziegler, R. (2011). An introduction to social entrepreneurship. Cheltenham, UK: Edward Elgar Publishing. 


\section{Authors}

The contribution share of authors is equal and amounted to $50 \%$ for each of them.

Anh Bui Ngoc Tuan - conceptualisation, literature writing, Minh Pham - methodology, calculations, discussion.

\section{Anh Bui Ngoc Tuan}

PhD Student at Ho Chi Minh city Open University. His research interests include social marketing, entrepreneurship.

Correspondence to: Anh Bui Ngoc Tuan, PhD Student, Department of Marketing, Faculty of Business Administration, Ho Chi Minh city Open University, 35 - 37 Ho Hao Hon, Ho Chi Minh city Vietnam, email: anh.bnt@ou.edu.vn ORCID (1) http://orcid.org/0000-0002-9130-4944

\section{Minh Pham}

PhD in Business Administration (2019). Vice head of Administration department, Ho Chi Minh city Open University. His research interests include social marketing, start-up, supply chain management.

Correspondence to: Minh Pham, PhD, Department of Administration, Faculty of Business Administration, Ho Chi Minh city Open University, 35 - 37 Ho Hao Hon, Ho Chi Minh city Vietnam, email: minh.p@ou.edu.vn ORCID (1) http://orcid.org/0000-0003-4200-0810

\section{Acknowledgements and Financial Disclosure}

The article is a part of project no. 01/E2021.14.1 entitled 'Extending the theory of planned behavior in predicting social entrepreneurial intention' financed by Ho Chi Minh City Open University conducted by Anh Bui Ngoc Tuan in the years 2021.

\section{Conflict of Interest}

The authors declare that the research was conducted in the absence of any commercial or financial relationships that could be construed as a potential conflict of interest.

\section{Copyright and License}

This article is published under the terms of the Creative Commons

Attribution - NoDerivs (CC BY-ND 4.0) License

http://creativecommons.org/licenses/by-nd/4.0/ 